\title{
Pengaruh Kualitas Produk Kosmetik Batrisyia Terhadap Loyalitas Konsumen (Studi pada Queen Batrisyia Muara Bungo)
}

\author{
Neti Zuhelti \\ Institut Agama Islam Yasni Bungo \\ Email : netizuheltime@gmail.com \\ Lina Ade Chusmita \\ Institut Agama Islam Yasni Bungo \\ Email : linaadechusmita@gmail.com \\ Busriadi \\ Institut Agama Islam Yasni Bungo \\ Email : bbusriadi@gmail.com
}

\begin{abstract}
This study aims to determine whether there is an effect of the quality of Batrisyia Cosmetics Products on Consumer Loyalty to Queen Batrisyia Muara Bungo. The background of this research is that there have been several problems in the management of Queen Batrisyia, resulting in a decrease in income and the number of consumers in purchasing products, this of course automatically results in a decrease in business turnover. This problem is also exacerbated by the number of consumer complaints about the quality of the product. From some of the problems above, the authors indicate that there is consumer dissatisfaction with the product, because many consumers do not feel suitable in using the product. Research This research uses a quantitative approach using Simple Linear Regression analysis. The research sample consisted of 60 respondents using a simple random sampling technique (simple random sampling). Data were analyzed using SPSS statistics (Statistical Package for the Social Sciences) Version 20.0. Based on the results of simple linear regression analysis, it was obtained that $\mathrm{a}=$ constant value of 9.815 , which means that product quality $(\mathrm{X})$ is constant $(0)$, so consumer loyalty is equal to 9.815 . While $b=$ regression coefficient value of 0.160 means that every $1 \%$ increase in product quality (X), will encourage Consumer Loyalty (Y) of 0.160 . The partial test results show that the Product Quality variable $(\mathrm{X})$ on the Consumer Loyalty variable $(\mathrm{Y})$ has a significant influence. Based on the coefficient of determination test (R2) there is a significant influence between the Product Quality (X) variable on the Consumer Loyalty variable (Y) with a contribution of $26.6 \%$.
\end{abstract}

Keywords: Product Quality and Consumer Loyalty 


\begin{abstract}
Abstrak
Penelitian ini bertujuan untuk mengetahui adakah Pengaruh Kualitas Produk Kosmetik Batrisyia Terhadap Loyalitas Konsumen pada Queen Batrisyia Muara Bungo. Adapun yang melatarbelakangi penelitian ini adalah telah terdapat beberapa permaslahan di dalam pengelolaan manajemen Queen Batrisyia, sehingga terjadi penurunan pendapatan dan jumlah konsumen dalam pembelian produk, hal ini tentunya secara otomatis berimbas kepada penurunan omset usaha. Permaslaahan tersebut juga diperkeruh dengan banyaknya keluhan konsumen atas kualitas produk. Dari beberapa permasalahan di atas, penulis mengindikasikan bahwa adanya ketidakpuasan konsumen terhadap produk, karena banyak konsumen tidak merasa cocok dalam menggunakan produk tersebut. Penelitian Penelitian ini menggunakan pendekatan kuantitatif dengan menggunakan analisis Regresi Linear Sederhana. Sampel penelitian terdiri 60 orang responden menggunakan teknik persampelan acak dan sederhana (simle random sampling). Data dianalisis menggunakan statistik SPSS (Statistical Package for the Sosial Sciences) Versi 20.0. Berdasarkan hasil uji analisis regresi linear sederhana didapatkan a = Nilai konstanta sebesar 9,815, yang mempunyai arti bahwa Kualitas Prosuk (X) bernilai konstan (0), maka Loyalitas Konsumen sama dengan 9,815. Sedangkan $b=$ Nilai koefisien regresi sebesar 0,160 ini bermakana bahwa setiap terjadi peningkatan $1 \%$ pada kualitas produk $(\mathrm{X})$, akan mendorong Loyalitas Konsumen (Y) sebesar 0,160. Hasil uji secara parsial menunjukkan bahwa variabel Kualitas Produk (X) terhadap variabel Loyalitas Konsumen (Y) mempunyai pengaruh secara signifikan. Berdasarkan uji koefisien determinasi $\left(\mathrm{R}^{2}\right)$ terdapat pengaruh signifikan antara variabel Kualitas Produk (X) terhadap variabel Loyalitas Konsumen (Y) dengan kontribusi pengaruh sebesar 26,6\%.
\end{abstract}

Kata Kunci: Kualitas Produk dan Loyalitas Konsumen.

\title{
A. Pendahuluan
}

Good looking atau penampilan paripurna baru-baru ini sudah mendarah daging di kalangan masyarakat, terutama kaum wanita. Untuk mendukung penampilan yang baik seperti yang diinginkan tak jarang jika masyarakat akan berikhtiar untuk mencari sesuatu yang dapat mewujudkan keinginannya tersebut. Salah satu cara untuk mendukung penampilan yang baik adalah dengan mempunyai tampilan muka (wajah) yang sehat, bersih, sehingga enak dipandang dan nyaman dirasakan, terutama bagi orang yang bersangkutan. Sekarang perawatan kecantikan sudah menjadi hal yang lumrah dan bahkan beberapa orang sudah menganggapnya sebagai salah satu kebutuhan hidup.

Melihat fenomena tersebut, para pengusaha, khususnya influencer di bidang kosmetik tampaknya tidak menyianyiakan kesempatan ini untuk terus membuka luas ladang usaha dengan mengembangkan berbagai pengembangan produk guna merebut hati para konsumen. Menariknya lagi, influencer di bidang kecantikan tersebut tidak hanya dari kalangan orang biasa berbisnis, bahkan 
dari kalangan artis yang memanfaatkan ketenaran namanya di dunia hiburanpun ikut andil dalam perkembangan dunia bisnis produk-produk kecantikan. Sehingga dalam 5 tahun terakhir sampai detik ini bergitu banyak bermunculan produk-produk kosmetik (produk kecantikan) yang bermunculan, mulai dari yang berorientasi herbal, halal, premium dan sampailah kepada paket perawatan exlusive, juga ditawarkan secara bebas di pasaran. Namun, fokus penelitian ini adalah pada produk-produk yang berorientasi halal yang sekarang masih marak di kalangan masyarakat terutama masyarakat Bungo, yaitu produk-produk yang diluncurkan oleh Queen Batrisyia.

Produk dari Batrisyia herbal merupakan salah satu produk kosmetik yang berbahan herbal dari Indonesia dengan omset sampai miliaran per tahun. Batrisyia Herbal adalah salah satu produk kosmetik dan juga perawatan yang sangat populer bagi wanita indonesia. Produk Batrisyia herbal ini memiliki popularitas yang sangat tinggi karena produk ini memiliki keunggulan. Keunggulan utama yang dimiliki oleh produk ini adalah banyaknya varian produk yang bisa memberikan manfaat untuk perawatan mulai dari ujung rambut hingga ke ujung kaki. Keunggulan lainnya yaitu, produk-produk tersebut juga mempunyai tinkat penyesuaian pemakaian yang dapat dipilih sesuai dengan kondisi kulit konsumen. selain itu, produk-produk Queen Batrisyia sangat mudah ditemukan, tidak hanya digerai resmi yang mudah dijumpai di took-toko, bahkan layanan untuk mempermudah konsumen mendapatkan produkuk pun sangat banyak, mulai dari pembelian secara online serta pembelian di reseller-reseller juga bisa dilakukan, khususnya di daerah Muara Bungo.

Namun, kinerja yang dilakukan oleh Queen Batrisyia untuk memenuhi keinginan konsumen seperti yang telah kita bahas di atas, ternyata tidak mendapat respon yang cukup baik dari konsumen. Hal ini dapat dibuktikan, dalam tiga tahun terakhir telah terjadi penurunan minat konsumen terhadap produk-produk yang diluncurkan oleh Batresyia Herbal khususnya di daerah Muara Bungo. Hal ini dapat kita amati dalam tabel data konsumen pengguna produk Batrisyia Herbal, sebagai berikut:

Tabel 1

Data Konsumen Queen Batrisyia Muara Bungo tahun 2017-2019

\begin{tabular}{|cc|}
\hline \multicolumn{1}{|c|}{ Tahun } & Jumlah (Orang) \\
\hline 2017 & 450 \\
\hline 2018 & 375 \\
\hline 2019 & 250 \\
\hline Jumlah & $\mathbf{1 . 0 7 5}$ \\
\hline Sunber: Queen Batrisyia Herbal Muara Bungo, 2020
\end{tabular}

Berdasarkan data di atas, kita dapat tahu bahwa ternyata pengembangan produk yang dilakukan oleh Batrisyia Herbal tidak mendapat respon baik dari para konsumen tiga tahun belakangan ini. Hal ini tentunya juga akan sangat berimbas dengan penurunan pendapatan. Hal ini dapat dibuktikan pada data berikut: 
Tabel 2

Data Pendapatan Queen Batrisyia Muara Bungo 2017-2019

\begin{tabular}{|cc|}
\hline Tahun & Pendapatan \\
\hline 2017 & Rp 800.026.000 \\
\hline 2018 & Rp 650.675.000 \\
\hline 2019 & Rp 450.760.000 \\
\hline \multicolumn{2}{|c|}{ Sumber: Queen Batrisyia Herbal Muara Bungo, 2020. }
\end{tabular}

Dari data di atas, dapat dilihat bahwa kemerosotan pendapatan dan hilangnya konsumen merupakan pukulan terbesar bagi seorang influencer khususnya dibidang produk kecantikan, tidak terkeculai yang seperti yang dialami oleh batresyia Herbal. Hal ini dikarenakan perusahaan yang terusmenerus kehilangan konsumen akan sulit menstabilkan penjualan karena harus selalu mencari konsumen baru. Apalagi jika perusahaan tersebut bergerak di bidang kecantikan. Di mana pada bidang ini, perusahaan dituntut untuk mampu menawarkan produk kecantikan yang baik untuk digunakan secara berkelanjutan.

Berdasarkan survey yang penulis lakukan peneliti juga menemukan permasalahan yang didominasi oleh keluhan konsumen yang berkaitan dengan kualitas produk. Hal tersebut minat konsuem yang menurun juga dikarekan adanya ketidakpuasan konsumen terhadap produk, karena banyak konsumen tidak merasa cocok dalam menggunakan produk tersebut. Mengingat persaingan dalam perkembangan dunia kecantikan, tidak mudah dan tidak sedikit, permasalahn-permasalahan di atas sangat penting untuk diketahui agar dapat terus bertahan dalam persaingan usaha terlebih lagi juga dapat lebih memperhatikan kebutuhan konsumen.

Berdasarkan uraian permasalahan di atas maka peneliti tertarik untuk menulis sebuah penelitian yang judul "Pengaruh Kualitas Produk Kosmetik Batrisyia Terhadap Loyalitas Konsumen (Studi pada Queen Batrisyia Muara Bungo)".

B. Landasan Teori

American Sociaty For Quality Control, mendefinisikan kualitas adalah totalitas fitur dan karakteristik produk atau jasa yang bergabung pada kemampuannya untuk memuaskan kebutuhan yang dinyatakan atau tersirat. ${ }^{1}$ Sedangakan menurut Kotler dan Gerry Amstrong, kualitas yaitu kemampuan suatu produk untuk melaksanakan fungsinya, meliputi daya tahan keandalan, ketepatan, kemudahan operasi dan perbaikan serta atrbut bernilai lainnya. ${ }^{2}$ Sehingga dapat disimpulkan bahwa mutu atau kualitas yaitu keseluruhan ciriciri dan karakteristik dari suatu produk atau jasa yang mampu memuaskan dan memenuhi kebutuhan-kebutuhan yang telah diinginkan. Derajat mutu produk di pasar dapat dikelompokkan dalam input tingkat yaitu rendah rata-rata, tinggi dan istimewa.

Menurut Kotler dan Amstrong, produk adalah segala sesuatu yang dapat ditawarkan kepasar untuk mendapatkan perhatian, dibeli, digunakan, atau

1 Philip Kotler \& Kevin Lane Keller, Manajemen Pemasaran, Erlangga, Jakarta, 2015, hal. 143

2 Ibid, hal. 34-35 
dikonsumsi yang dapat memuaskan keinginan atau kebutuhan. Trend dapat menyebabkan terjadinya perubahan pada segmen pasar yang ada. Berkenaan dengan itu fokus dalam penelitian ini adalah permasalahan yang terjadi pada klinik-klinik kecantikan menyebabkan semakin banyak pula pelayanan yang ditawarkan kepada konsumen, hal ini akan memberikan kesempatan kepada konsumen untuk dapat memilih dan membeli produk yang sesuai dengan keinginan dan kebutuhan konsumen. ${ }^{3}$

Kualitas produk menurut Tjiptono, adalah kualitas yang mencerminkan semua dimensi penawaran produk yang menghasilkan manfaat (benefits) bagi pelanggan. Kualitas suatu produk baik berupa barang atau jasa ditentukan melalui dimensi-dimensinya. ${ }^{4}$ Kualitas produk merupakan hal penting yang harus diusahakan oleh setiap perusahaan jika ingin yang dihasilkan dapat bersaing di pasar untuk memuaskan kebutuhan dan keinginan konsumen. Kuhal ini dikarenakan kualitas adalah syarat utama diterimanya suatu produk di pasar. Suatu produk dikatakan berkualitas apabila produk tersebut mampu memenuhi harapan konsumen. Berbagai usaha ditempuh perusahaan untuk menghasilkan produk yang berkualitas, antara lain dengan menerapkan kontrol yang ketat pada setiap proses mulai dari penyiapan bahan baku sampai penyimpanan produk jadi. Sebagian besar konsumen semakin kritis dalam mengkonsumsi suatu produk. Konsumen selalu ingin mendapatkan produk yang berkualitas sesuai dengan harga yang dibayar, meskipun ada sebagian masyarakat berpendapat bahwa, produk yang mahal adalah produk yang berkualitas. Kualitas produk yang baik dan harga terjangkau merupakan pertimbangan sendiri bagi konsumen yang akan membeli produk tertentu. Adapun yang mempengaruhi kualitas produk diantaranya yaitu: funsi suatu produk, wujud luar dan biaya produk. Beberapa faktor ini lah yang dapat mempengaruhi loyalitas konsumen terhadap suatu prouduk.

Secara harfiah loyal berarti setia, atau loyalitas dapat diartikan sebagai suatu kesetiaan. Kesetiaan ini timbul tanpa adanya paksaan, tetapi timbul dari kesadaran sendiri pada masa lalu. Usaha yang dilakukan untuk menciptakan kepuasan konsumen lebih cenderung mempengaruhi sikap konsumen. Sedangkan konsep loyalitas konsumen lebih menekankan kepada perilaku pembeliannya. ${ }^{5}$ Sehingga loyalitas secara sederhana dapat dipahami sebagai pilihan yang dilakukan konsumen untuk membeli merek tertentu dibandingkan merek yang lain dalam kategori produk yang sama.

Sedangkan konsumen adalah setiap orang atau keluarga yang mendapatkan barang untuk dipakai dan untuk tidak diperdagangkan. ${ }^{6}$ Konsumen menurut Kotler dan Keller, adalah sebagai orang yang membeli produk dari orang lain. Banyak perusahaan yang tidak mencapai kesuksesan karena mengabaikan konsep konsumen. Konsumen, saluran distribusi, dan pasar adalah objek biaya yang memiliki keragaman pada produk. Konsumen dapat mengkonsumsi aktivitas yang digerakkan oleh konsumen yaitu frekuesni

\footnotetext{
${ }^{3}$ Ummu Habibah \& Sumiati, Pengaruh Kualitas Produk Dan Harga Terhadap Keputusan Pembelian Produk Kosmetik Wardah Di Kota Bangkalan Madura, Jurnal Ekonomi \& Bisnis, Vol 1 No. 1 Maret 2016, hal. 34-35

${ }^{4}$ Giardo Permadi Putra, Et.al, Pengaruh Kualitas Produk Terhadap Keputusan Pembelian dan Dampaknya Terhadap Kepuasan Konsumen, Jurnal Administrasi Bisnis (JAB), Vol. 48 No. 1 Juli 2017, hal. 125

5 Friantoni \& Ernawati, Analisis Perilaku, Kepuasan dan Loyalitas Konsumen Dalam Membeli Produk Kosmetik Merek Batrisyia Herbal

${ }^{6}$ Cindy Phasalita Widayatma, Pengaruh Kualitas Produk Terhadap Loyalitas Konsumen Kepuasan Konsumen Sebagai Variabel Intervening, Jurnal Ilmiah UNTAG Semarang, Vol. 7 No. 3, 2018, hal. 28
} 
pengiriman, penjualan dan dukungan promosi. Sehingga untuk mengetahui biaya yang dikeluarkan untuk melayani konsumen dengan tingkat kebutuhan yang berbeda-beda, perusahaan memperoleh informasi yang berguna dalam penetapan harga, penentuan bauran konsumen dan peningkatan profitabilitas. ${ }^{7}$ profit atau keuntungan sebuah usaha, sangat bergantung pada loyalitas konsumen terhadapat produk-produk yang ditawarkan.

Loyalitas konsumen secara umum yaitu kesetiaan seseorang atas suatu produk, baik barang maupun jasa tertentu. Loyalitas adalah bukti konsumen yang selalu menjadi pelanggan, yang memiliki kekuatan dan sikap positif atas perusahaan. Loyalitas konsumen menurut Sutisna dapat dikelompokkan kedalam dua kelompok yaitu loyalitas merek (brand loyalty) dan loyalitas toko (store loyalty). Loyalitas konsumen dapat adalah sebagai "sikap menyenangi terhadap suatu merek yang direpresentasikan dalam pembelian yang konsisten terhadap merek itu sepanjang waktu". ${ }^{8}$

\section{Metode Penelitian}

Penelitian ini menggunakan metode deskriptif dengan pendekatan kuantitatif. Menurut Sugiyono, metode penelitian kuantitatif adalah metode penelitian yang digunakan untuk meneliti populasi atau sampel tertentu dengan berlandaskan pada filsafat positivisme. Pengumpulan data menggunakan instrumen penelitian untuk menggambarkan dan menguji hipotesis yang telah ditetapkan, maka analisis data bersifat kuantitatif/statistik. ${ }^{9}$

Populasi adalah keseluruhan dari elemen atau unit penelitian yang memiliki karakteristik tertentu, yang sesuai dengan tujuan penelitian. Adapun populasi dalam penelitian ini adalah seluruh konsumen Batrisyia Herbal yang ada di Muara Bungo. Dengan demikian populasi yang digunakan adalah bersifat tidak terbatas. Sedangkan untuk mempermudah dan dalam rangka menghemat waktu untuk itu penulis melakukan pensampelan dalam penelitian ini. Dalam menentukan sampel peneliti menggunakan teknik Non-probability sampling atau pemilihan sampel tidak acak. Adapun metode pengambilan sampel adalah dengan cara pembagikan angket kuisioner kepada responden secara langsung, dengan menggunakan Accidential Sampling. Accidential Sampling, yaitu teknik pengambilan sampel yang tidak ditetapkan terlebih dahulu. Jadi, peneliti langsung mengumpulkan data dari unit sampling yang ditemui, setelah jumlah responden diperkirakan mencukupi, maka pengumpulan data dihentikan. Ini bermakna, bahwa setiap populasi memiliki hak yang sama untuk memberikan respon melalui angket yang penulis bagikan, namun dalam pembagian angket tersebut penulis membagikan angket secara tidak acak kepada konsumen yang menjadi responden dalam penelitian ini. Dari metode pensampelan ini, jumlah responden yang telah penulis teliti adalah sebanyak 60 orang.

Selanjutnya dari hasil pengumpulan kuesioner tesebut, peneliti menggunakan alat analisis berupa softwere SPSS (Statistical Package for the Sosial Sciences) Versi 20.0 untuk menganalisis data. Sedangkan untuk memudahkan dalam mengukur data, penulis menggunakan skala likert.

\footnotetext{
${ }^{7}$ Friantoni \& Ernawati, Op.Cit, hal. 4

8 Anggraeni, Dita Putri, dkk. 2016. Pengaruh Kualitas Produk Terhadap Kepuasan dan Loyalitas Pelanggan. Jurnal Admisnistrasi Bisnis (JAB). Vol. 37

${ }^{9}$ Sugiyono, Metode Penelitian Administrasi dan Metode R\&D, Alfabeta, Bandung, 2013, hal. 65
} 
Selanjutnya, setelah semua data terinput penulis analisis menggunakan teknik analisis regresi linear sederhana. Regresi linear sederhana adalah salah satu teknik analisis yang digunakan untuk mengetahui hubungan antara variabel independen dan variabel dependen. ${ }^{10}$

D. Hasil dan Pembahasan

Awal pertama kali Batrisyia Herbal masuk ke Muara Bungo pada tanggal 12 Januari 2016. Saat itu ada seorang perempuan yang menggunakan produk dari Batrisyia Herbal selama satu tahun lamanya dan dia berhasil membuat kulit wajah nya menjadi bersih alami karena menggunakan produk dari Batrisyia. Dan pada tanggal 15 Januari 2017 dia berkesempatan menjadi agen distributor utama dari Batrisyia Herbal, dan dia memberi nama tokonya menjadi Queen Batrisyia Herbal. Berkat keuletannya ia sekarang telah memiliki empat orang karyawan.

Berdasarkan data penelitian yang didapat melalui kuesioner, peneliti telah mendapatkan responden yang berusia kurang dari 25 tahun sebanyak 15 orang (25\%), Sedangkan responden dengan usiah 26-30 tahun sebanyak 25 orang (40\%). Selanjutnya responden dengan usia lebih dari 30 tahun adalah sebanyak 21 orang (35\%). Berikut adalah karakteristik responden berdasarkan pekerjaan yang peneliti dapatkan:

Tabel 3

karakteristik Responden Berdasarkan Pekerjaan

\begin{tabular}{|clcc|}
\hline No & \multicolumn{1}{c}{ Pekerjaan } & Frekuensi & Persentase \\
\hline 1 & Mahasiswa/Pelajar & 16 & $26,7 \%$ \\
\hline 2 & PNS & 6 & $10 \%$ \\
\hline 3 & Polwan & 6 & $10 \%$ \\
\hline 4 & Wiraswasta/Wirausaha & 13 & $21,7 \%$ \\
\hline 5 & Ibu Rumah Tangga & 19 & $31,7 \%$ \\
\hline & Jumlah & $\mathbf{6 0}$ & $\mathbf{1 0 0 \%}$ \\
\hline
\end{tabular}

Sumber: Data Primer yang diolah, 2020

Berdasarkan tabel diatas, dapat didefinisikan bahwa responden pada penelitian ini memiliki pekerjaan yang berbeda, sebagai mahasiswa/pelajar 16 orang dengan nilai persentase sebesar 26,7\%, sementara pns dan polwan 6 orang dengan persentase $10 \%$ merupakan data terendah, sedangkan wiraswasta/wirausaha 13 orang dengan nilai persentasi sebesar 21,7\%, sedangkan ibu rumah tangga sebanyak 19 orang dengan persentase sebesar $31,7 \%$.

1. Hasil Analisis Data

a. Analisis Deskriptif Variable Kualitas Produk

Hasil rekapitulasi analisis dari masing-masing indikator pada variabel kualitas produk adalah sebagai berikut:

Tabel 4

Rekapitulasi Rata-rata TCR Indikator Variabel Kualitas Produk

\begin{tabular}{|clcc|}
\hline No & \multicolumn{1}{c}{ Indikator } & TCR (\%) & Kategori \\
\hline $\mathbf{1}$ & Kinerja & 75,50 & Cukup Baik \\
\hline $\mathbf{2}$ & Fitur & 71,00 & Cukup Baik \\
\hline $\mathbf{3}$ & Kehandalan & 428,9 & Sangat Baik \\
$\mathbf{4}$ & Kesesuain & 71,00 & Cukup Baik \\
\hline
\end{tabular}

${ }^{10}$ Suyono, Analisis Regresi Untuk Penelitian, Budi Utama, Jakarta, 2015, hal. 5 
Neti Zuhelti, Lina Ade Chusmita, Busriadi :Pengaruh Kualitas Produk...26

\begin{tabular}{|c|c|c|c|}
\hline 5 & Daya Tahan & 73,60 & Cukup Baik \\
\hline 6 & Estetika & 75,75 & Cukup Baik \\
\hline 7 & $\begin{array}{l}\text { Kualitas } \\
\text { Dipersepsikan }\end{array}$ & 73,60 & Cukup Baik \\
\hline & ta-rata Indikator & 124,1 & Sangat Baik \\
\hline
\end{tabular}

Sumber: Data Primer yang diolah, 2020

b. Analisis Deskriptif Variabel Loyalitas Konsumen

Hasil analisis deskriptif variabel Loyalitas Konsumen dalam penelitian ini adalah:

Tabel 5

Rekapitulasi Rata-rata TCR Indikator Variabel Loyalitas Konsumen

\begin{tabular}{|c|c|c|c|}
\hline No & Indikator & $\begin{array}{l}\text { TCR } \\
(\%)\end{array}$ & Kategori \\
\hline 1 & $\begin{array}{l}\text { Kepuasan Menggunakan } \\
\text { Produk }\end{array}$ & 74,10 & Cukup Baik \\
\hline 2 & $\begin{array}{l}\text { Berkomitmen Menggunakan } \\
\text { Produk }\end{array}$ & 76,60 & Cukup Baik \\
\hline 3 & $\begin{array}{l}\text { Merekomendasikan Produk } \\
\text { Kepada Orang Lain }\end{array}$ & 67,90 & Cukup Baik \\
\hline 4 & Tidak Mencoba Produk Lain & 62,60 & Cukup Baik \\
\hline 5 & $\begin{array}{l}\text { Melakukan } \quad \text { Pembelian } \\
\text { Produk Secara Berulang }\end{array}$ & 65,90 & Cukup Baik \\
\hline & Rata-rata Indikator & 64,42 & $\begin{array}{c}\text { Cukup } \\
\text { Baik }\end{array}$ \\
\hline
\end{tabular}

Sumber: Data Primer yang diolah, 2020

\section{c. Regresi Linier Sederhana}

Berdasarkan hasil analisis yang peneliti lakukan, output dari analisis regresi linier sederhana ini adalah sebagai berikut:

Tabel 6

Hasil Analisis Regeresi Linier Sederhana

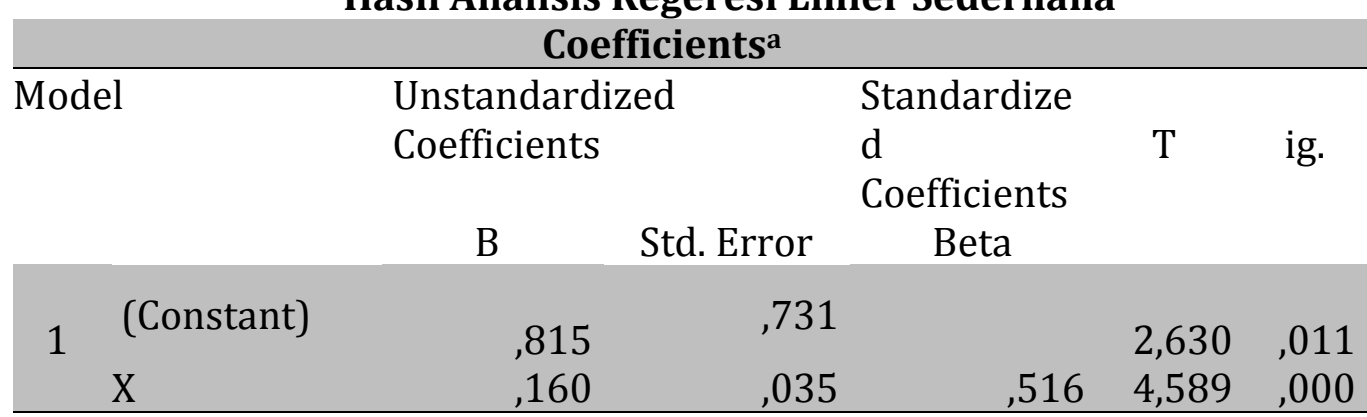

Sumber: Data diolah, 2020

Keterangan:

a. Dependent Variable: Y

Berdasarkan ouput diatas dapat diperoleh persamaan $(\mathrm{Y}=\mathrm{a}+\mathrm{bx}+\mathrm{e})$ hasil regresi Kualitas Produk (X), terhadap Loyalitas Konsumen (Y) adalah Y= $9,815+0,160 X+e$. Berdasarkan nilai koefisien regresi dan variabel yang mempengaruhi Kualitas produk (X) dengan menggunakan tingkat signifikan $\alpha=0,05$ maka, hasil analisis ini dapat diinterprestasikan sebagai berikut: $\mathrm{a}=$ Nilai konstanta sebesar 9,815 menunjukkan bahwa jika kualitas produk atau 
X bernilai konstan atau 0, maka Loyalitas Konsumen sama dengan 9,815. Sedangkan $\mathrm{b}=$ Nilai koefisien 0,160 menunjukkan bahwa setiap terjadi peningkatan $1 \%$ pada kualitas produk, akan mendorong Loyalitas Konsumen sebesar 0,160.

\section{d. Hasil Uji Validitas}

Uji validitas merupakan ukuran yang menunjukan tingkat kesahihan suatu alat ukur atau instrumen (kuesioner). Kuesioner dikatakan valid jika pernyataan pada kuesioner mampu mengungkapkan sesuatu yang akan diukur. Jika $r_{\text {hitung }}$ lebih besar dari $r_{\text {tabel }}$ maka alat ukur tersebut dapat dikatakan valid atau signifikan. Adapun nilai $r_{\text {tabel }}$ pada tingkat signifikan 0,05 adalah 0,214. Dengan menggunakan rumus $\mathrm{Df}=(\mathrm{n}-2)=60-2=58$. Hasil uji validitas dengan menggunakan SPSS 20, sehingga hasil yang didapat adalah semua item pernyataan variabel kualitas produk (X) berkorekasi signifikan. Karena nilai r-hitung diperoleh lebih besar dari pada r-tabel $(0,214)$, maka dapat disimpulkan bahwa semua instrument pada variabel Kualitas Produk (X) dinyatakan valid tersebut. Sedangakan item pernyataan untuk variabel loyalitas konsumen (Y) berkolerasi signifikan. Karena nilai rhitung yang diperoleh lebih besar dari nilai $r$-tabel $(0,214)$, maka dapat disimpulkan bahwa semua instrument pada variabel loyalitas konsumen (Y) semua dinyatakan valid.

\section{e. Hasil Uji Rentabilitas}

Reliabilitas bertujuan untuk mengetahui sejauh mana hasil pengukuran tetap konsisten, apabila dilakukan pengukuran ulang pada waktu yang berbeda maka akan menghasilkan hasil yang sama atau mendekati. Forumula yang digunakan untuk menguji reliabilitas dalam penelitian ini adalah dengan rumus Koefisien Alpha (a) dari Cronbach yaitu :

a. Jika nilai Cronbach's Alpha $\left(\mathrm{r}_{11}\right),>0,6$ maka item variabel dinyatakan reliabel.

b. Jika nilai Cronbach's Alpha ( $\left.\mathrm{r}_{11}\right),<0,6$ maka item variabel dinyatakan tidak reliabel.

Berikut disajikan hasil uji reliabilitas dengan menggunakan SPSS 20 yang dapat dilihat melalui tabel sebagai berikut:

\section{Tabel 7}

Hasil Uji Rentabilitas

\begin{tabular}{cccc}
\hline Variabel & Nilai Cronbach & Standar & Keterangan \\
$\begin{array}{c}\text { Kualitas Produk } \\
(\mathrm{X})\end{array}$ & 0,901 & 0,6 & Reliabel \\
$\begin{array}{c}\text { Loyalitas Konsumen } \\
(\mathrm{Y})\end{array}$ & 0,784 & 0,6 & Reliabel \\
\hline
\end{tabular}

Sumber: Data Diolah, 2020

Berdasarkan data di atas dapat diketahui bahwa variabel Kualitas Produk (X) memiliki nilai Cronbach Alpha sebesar 0,901 > 0,6, variabel Loyalitas Konsumen (Y) memiliki nilai Cronbach Alpha sebesar 0,784 >0,6, artinya dapat dinyatakan bahwa semua data dinyatakan Reliabel.

\section{f. Uji Normalitas}

Uji normalitas data merupakan uji distribusi data yang akan dianalisis, apakah penyebarannya di bawah kurva normal atau tidak, distribusi normal adalah distribusi yang bentuknya seperti lonceng dan simetris.

a. Jika Signifikansi (Sig.) > 0,05 maka nilai residual berdistribusi normal. 
b. Jika Signifikansi (Sig.) $<0,05$ maka nilai residual tidak berdistribusi normal.

Berdasarkan ouput SPSS, diketahui bahwa nilai signifikan Asymp. Sig (2-tailed) sebesar 0,655 lebih besar dari 0,05. Maka sesuai dengan pengambilan keputusan dalam uji normalitas kolmogorov-smirnov di atas dapat disimpulkan bahwa data berdistribusi normal. Dengan demikian, asumsi atau persyaratan normalitas dalam model regresi sudah terpenuhi.

\section{g. Hasil Pengujian Hipotesis}

Hasil parsial bertujuan untuk mengetahui apakah variabel bebas atau variabel independen secara parsial (sendiri-sendiri) berpengaruh terhadap variabel terikat atau variabel dependen. Adapun variabel independen yaitu Kualitas Produk (X), dan variabel dependen yaitu Loyalitas Konsumen (Y). Hasil keputusan dapat dikatakan sebagai berikut :

\section{Tabel 8}

Hasil Uji t (Persial)

\begin{tabular}{|c|c|c|c|c|c|}
\hline \multirow[b]{3}{*}{ Model } & \multicolumn{3}{|c|}{ Coefficients ${ }^{a}$} & \multirow[b]{3}{*}{$\mathrm{t}$} & \multirow[b]{3}{*}{ Sig. } \\
\hline & \multicolumn{2}{|c|}{$\begin{array}{c}\text { Unstandardized } \\
\text { Coefficients }\end{array}$} & $\begin{array}{l}\text { Standardized } \\
\text { Coefficients }\end{array}$ & & \\
\hline & $B$ & Std. Error & Beta & & \\
\hline 1 (Constant) & ,815 & 3,731 & & ,630 &, 011 \\
\hline & 160 & ,035 & ,516 & 4,589 &, 000 \\
\hline
\end{tabular}

Sumber : Data diolah (Output SPSS Versi. 20), 2020

Ketetangan:

a. Dependent Variable: Y

Berdasarkan hasil uji t diperoleh nilai t hitung sebesar 4,589 > t tabel 1,671 dan tingkat signifikan 0,000 $<0,05$ yang berarti bahwa Ho ditolak dan Ha diterima dapat disimpulkan bahwa terdapat pengaruh signifikan antara variabel Kualitas Produk (X) terhadap variabel Loyalitas Konsumen (Y).

\section{h. Hasil Uji Koefisien Determinasi $\left(\mathrm{R}^{2}\right)$}

Koefisien determinasi merupakan besaran yang menunjukkan besarnya variasi variabel dependen yang dapat dijelaskan oleh variabel independennya. Dengan kata lain, koefisien determinasi ini digunakan untuk mengukur seberapa besar variabel bebas dalam menerangkan variabel terikatnya. Nilai koefisien determinasi ditentukan dengan nilai $R$ Square dapat dilihat pada tabel dibawah ini.

\section{Tabel 9}

\section{Hasil Uji Koefisien Determinasi $\left(\mathrm{R}^{2}\right)$}

\begin{tabular}{l|ccc}
\hline \multicolumn{4}{c}{ Model Summary $^{\mathbf{b}}$} \\
Model & $\mathrm{R} \quad \mathrm{R}$ Square & $\begin{array}{c}\text { Adjusted R } \\
\text { Square }\end{array}$ & $\begin{array}{c}\text { Std. Error of the } \\
\text { Estimate }\end{array}$
\end{tabular}

\begin{tabular}{lllll}
1 & $, 516^{\mathrm{a}} \quad, 266$ &, 254 & 4,425 \\
\hline
\end{tabular}

Sumber: Data Diolah, 2020.

Keterangan:

a. Predictors: (Constant), X

b. Dependent Variable: Y 
Berdasarkan tabel diatas nilai R adalah 0,516, jadi $K D=R^{2} \times 100=(0.516)^{2} \times$ $100=26,6 \%$. Dapat disimpulkan bahwa kontribusi variabel Kualitas Produk (X) mempengaruhi variabel Loyalitas Konsumen (Y) sebesar 26,6 \%.

\section{Pembahasan Hasil Penelitian}

Berdasarkan hasil pengujian Pengaruh Kualitas Produk Kosmetik Batrisyia terhadap Loyalitas Konsumen (Studi pada Queen Batrisyia Muara Bungo). Pada pengujian hipotesis berdasarkan hasil perhitungan dapat dikatakan bahwa Kualitas Produk (X) berpengaruh signifikan terhadap Loyalitas Konsumen (Y). Dalam penelitian ini, variabel kualitas produk berpengaruh signifikan terhadap loyalitas konsumen. Hal ini dikarenakan variabel kualitas produk didapatkan hasil uji t-hitung $4.589>\mathrm{t}$ tabel 1.671 dan tingkat signifikan $0.000<0.05$ yang berarti bahwa Ho ditolak dan Ha diterima dapat disimpulkan bahwa terdapat pengaruh signifikan antara variabel Kualitas Produk (X) terhadap variabel Loyalitas Konsumen (Y). Dalam hal ini berarti bahwa kinerja, fitur, kehandalan, kesesuaian, daya tahan, estetika, dan kualitas yang dipersepsikan. Mempengaruhi konsumen untuk membeli produk kembali. Apabila kualitas suatu produk semakin baik maka loyalitas konsumen semakin tinggi.

Berdasarkan hasil uji koefisien determinasi diperoleh nilai $\mathrm{R}$ adalah 0.516 , jadi $K D=R^{2} \times 100=(0,516)^{2} \times 100=26,6 \%$. Dapat disimpulkan bahwa kontribusi variabel Kualitas Produk (X) mempengaruhi variabel Loyalitas Konsumen (Y) sebesar 26,6 \%. Dan selebihnya dipengaruhi oleh variabel lain diluar penelitian.

Adapun penelitian yang mendukung hasil penelitian ini adalah Dita Putri Anggraeini, Srikandi Kumadji dan Sunarti tahun 2016 dengan judul penelitian Pengaruh Kualitas Produk Terhadap Kepuasan dan Loyalitas Pelanggan (Survei pada Pelanggan Nasi Rawon di Rumah Makan Sakinah Kota Pasuruan) dengan hasil penelitian menyatakan bahwa kualitas produk terbukti memiliki pengaruh signifikan terhadap loyalitas pelanggan.

Penelitian dari Cindy Phasalita Widayatama dan Sri Puji Lestari tahun 2018 dengan judul Pengaruh Kualitas Produk terhadap Loyalitas Konsumen dengan Kepuasan Konsumen sebagai Variabel Intervening (Studi kasus pada Rifa Kuliner Kendal) dengan hasil penelitian kualitas produk terbukti berpengaruh terhadap loyalitas konsumen.

Penelitian dari Riska Asnawi Nyonyie, J.A.F. Kalangi dan Lucky F. Tamengkel tahun 2019 dengan judul Pengaruh Kualitas Produk Terhadap Loyalitas Pelanggan Kosmetik Wardah di Transmart Bahu Manado dengan hasil penelitian terdapat pengaruh yang terbilang cukup kuat yang menyatakan ada pengaruh variabel kualitas produk terhadap variabel loyalitas pelanggan dan berdasarkan hasil penelitian bahwa kualitas produk berpengaruh terhadap loyalitas pelanggan karena memiliki nilai yang signifikan yang berarti ada pengaruh kualitas produk dan loyalitas pelanggan memiliki hubungan yang positif.

\section{E. KESIMPULAN DAN SARAN}

\section{a. Kesimpulan}

Berdasarkan analisis data yang dikumpulkan dan diolah maka dapat disimpulkan bahwa : 
1. Penelitian ini dilakukan dengan menyebarkan kuesioner kepada 60 responden dengan total pernyataan sebanyak 33 item. Responden dalam penelitian ini secara kebetulan yang artinya siapa saja yang bertemu dengan peneliti pada saat penelitian maka dapat dijadikan sebagai sampel.

2. Berdasarkan hasil uji analisis regresi linear sederhana didapatkan $\mathrm{a}=$ Nilai konstanta sebesar 9,815 menunjukkan bahwa jika kualitas produk atau X bernilai konstan atau 0, maka loyalitas konsumen sama dengan 9,815. b = Nilai koefisien 0,160 menunjukkan bahwa setiap terjadi peningkatan $1 \%$ pada kualitas produk, akan mendorong loyalitas konsumen sebesar 0,160 .

3. Hasil uji secara parsial menunjukkan bahwa variabel Kualitas Produk (X) terhadap variabel Loyalitas Konsumen (Y) terdapat pengaruh secara signifikan.

4. Berdasarkan uji koefisien determinasi terdapat pengaruh signifikan antara variabel Kualitas Produk (X) terhadap variabel Loyalitas Konsumen (Y) dengan kontribusi pengaruh sebesar 26,6\%.

\section{b. Saran}

Adapun Saran yang dapat penulis sampaikan, yaitu :

1. Bagi pembaca pada umumnya, hendaknya penulisan skripsi ini dapat menjadi inspirasi dalam membuat tulisan-tulisan yang berkaitan dengan kualitas produk dan loyalitas konsumen.

2. Mengingat bahwa kualitas produk mempunyai pengaruh yang signifikan terhadap loyalitas konsumen, maka diharapkan Queen Batrisyia terus meningkatkan kualitas produknya agar konsumen setia akan produk tersebut dan tidak pindah ke produk yang lain.

3. Variabel yang digunakan dalam penelitian ini telah terbukti saling mempengaruhi satu sama lain, namun variabel lainnya di luar penelitian ini diindikasi kemungkinan memiliki pengaruh, sehingga disarankan untuk penelitian selanjutnya diharapkan dapat meneliti dengan variabelvariabel lain seperti harga, kepuasan konsumen dan kualitas pelayanan agar memperoleh hasil yang lebih beragam. 


\section{DAFTAR PUSTAKA}

Anggraeni, Dita Putri, dkk. 2016. Pengaruh Kualitas Produk Terhadap Kepuasan dan Loyalitas Pelanggan. Jurnal Admisnistrasi Bisnis (JAB). Vol. 37

Cindy Phasalita Widayatma, Pengaruh Kualitas Produk Terhadap Loyalitas Konsumen Kepuasan Konsumen Sebagai Variabel Intervening, Jurnal Ilmiah UNTAG Semarang, Vol. 7 No. 3, 2018, hal. 28

Friantoni \& Ernawati, Analisis Perilaku, Kepuasan dan Loyalitas Konsumen Dalam Membeli Produk Kosmetik Merek Batrisyia Herbal

Habibah, Ummu \& Sumiati. 2016. Pengaruh Kualitas Produk Dan Harga Terhadap Keputusan Pembelian Produk Kosmetik Wardah Di Kota Bangkalan Madura. Jurnal Ekonomi \& Bisnis. Vol. 1

Kotler, Philip \& Kevin Lane Keller. 2015. Manajemen Pemasaran. Jakarta: Erlangga

Putra, Giardo Permadi, dkk. 2017. Pengaruh Kualitas Produk Terhadap Keputusan Pembelian dan Dampaknya Terhadap Kepuasan Konsumen. Jurnal Administrasi Bisnis (JAB). Vol. 48

Sugiyono. 2013. Metode Penelitian Administrasi dan Metode R\&D. Bandung: Alfabeta

---.-. 2007. Metode Penelitian Administrasi. Bandung: Alfabeta

Suyono. 2015. Analisis Regresi Untuk Penelitian, Jakarta : Budi Utama. 